\title{
FOREIGN DIRECT INVESTMENT AND CONDITIONAL ACCOUNTING CONSERVATISM IN SOUTH ASIA
}

\author{
Isuru Manawadu*, Anna Che Azmi and Mohamed Aslam
}

\begin{abstract}
Research aim: The purpose of this study is to investigate the effect of foreign direct investment (FDI) on conditional accounting conservatism in South Asia. Design/ Methodology/ Approach: This study uses the model developed by Basu (1997), Ball and Shivakumar (2005), and Hämäläinen and Martikainen (2015) to examine the relationship between FDI and conditional accounting conservatism. Accounting data were obtained from all public listed companies other than financial companies in India, Pakistan, Bangladesh, and Sri Lanka for 2006 through 2015. The ordinary least squares (OLS) method in panel regression was used.
\end{abstract}

Research finding: The results indicate that a significant positive relationship exists between FDI and conditional accounting conservatism in South Asia as a whole, and the individual countries of India, Pakistan, and Bangladesh. However, FDI does not positively affect conditional accounting conservatism in Sri Lanka. Furthermore, emerging economies have more incremental conditional accounting conservatism on FDI than transitional economies.

Theoretical contribution/ Originality: The model used in this study makes an important contribution to the literature, which was confirmed by sensitivity testing. The result was more sensitive for the FDI variable. Also, the study confirmed that more incremental conditional accounting conservatism can be seen when using real FDI than when using a dummy FDI. This study extends the South Asian literature on conditional accounting conservatism and fills a gap in the empirical studies on FDI and conditional accounting conservatism.

Practitioner/ Policy implication: The results will be useful to policymakers and authoritative accounting bodies in the respective countries in South Asia to ensure the quality of financial reporting so as to facilitate FDI.

Research limitation/ Implication: This study used the conditional accounting conservatism to measure accounting quality. However, other methods such as

\footnotetext{
*Corresponding author: Isuru Manawadu is a lecturer at the Department of Interdisciplinary Studies, Faculty of Information Technology, University of Moratuwa, Sri Lanka; and PhD scholar at the Institute of Graduate Studies, University of Malaya 50603, Kuala Lumpur, Malaysia. Email: and imanawadu@uom.lk and hva170040@siswa.um.edu.my

Anna Che Azmi, PhD is an Associate Professor at the Department of Accounting, Faculty of Business and Accountancy, University of Malaya. 50603, Kuala Lumpur, Malaysia. Email: annaazriati@um.edu.my

Mohamed Aslam, PhD is a Senior lecturer at the Department of Economics, Faculty of Economics and Administration, University of Malaya. 50603, Kuala Lumpur, Malaysia. Email: maslam@um.edu.my
} 
earnings management, value relevance etc. for measuring accounting quality could be used with FDI in future researches.

Keywords: Accounting Quality, Foreign Investment, Emerging Economies, Conservatism

Type of manuscript: Research paper

JEL Classification: M41, F21, N40, M48

\section{Introduction}

Even though a country is able to attract foreign direct investment (FDI), the lack of conditional accounting conservatism would adversely affect the FDI of an emerging country more than in a developed country (Daniel \& Andres, 1999). In addition, Laura, Areendam, Sebnem and Selin (2004) argued that FDI plays a vital role to enhance economic growth, and, for that, conditional accounting conservatism is an important factor. A significant positive relationship exists between conditional accounting conservatism and FDI (Fortin, Barros, \& Cutler, 2010). However, this is only found in developed markets. A high level of FDI leads the incentives for highly conservative financial reporting, especially when the free flow of foreign capital is limited (Hämäläinen \& Martikainen, 2015). In less developed markets, Emeni (2014), for example, found a positive but not significant relationship between FDI and accounting quality in Africa.

In general terms, conditional accounting conservatism means that the accountant can anticipate all possible losses but not the possible profits for an organization. This accounts for the propensity towards a high degree of certification to recognize good news as gains and bad news as losses (Basu, 1997). The main purpose of this study is to examine the effect of FDI on conditional accounting conservatism in emerging economies by focusing on countries in South Asia from 2006 through 2015. By doing this, this study contributes to the emerging economies literature on FDI and conditional accounting conservatism. To investigate the link between FDI and conditional accounting conservatism in South Asia, India, Pakistan, Bangladesh, and Sri Lanka are selected. However, other countries of South Asia - Nepal, Bhutan, Afghanistan, and Maldives - are not considered due to the unavailability of accounting data.

The findings of this study will contribute to the South Asian literature on the correlation between FDI and conditional accounting conservatism. The results will be useful to policymakers and authoritative accounting bodies in the respective countries in South Asia to ensure the quality of financial reporting so as to facilitate FDI. Another contribution of this study is its use of actual FDI in the regression model. 
Real data exhibit more characteristics and have great simulation and feasibility in distribution (Stigler, 1977). To produce significant results, this study uses real data to strengthen its contribution. In addition, sensitivity testing is also conducted to show that FDI is a sensitive variable for the results.

The following section discusses the financial regulatory environment of South Asia and describes the authoritative accounting bodies. A literature review is then presented. Next, the development of the hypotheses and methodology sections are presented. Following this, the empirical results and conclusions of the study are presented.

\section{Financial Regulatory Environment in South Asia}

South Asian countries include Afghanistan, Bangladesh, Bhutan, India, Maldives, Nepal, Pakistan, and Sri Lanka. All South Asian countries still fall into the emerging category (World Bank, 2016). Unlike transitional economies, most South Asian countries show socialist ownership. However, foreign investors do not invest in many industries in South Asian countries due to the procedural delays and the reserved industries for which investment is prohibited (Sahoo, Nataraj, \& Dash, 2014). Comparatively, countries that have socialist ownerships have less transparent policies than transitional economies (Luo \& Peng, 1998).

Overall, the Companies Act and professional accounting bodies, such as the respective Institutes of Chartered Accountants, largely govern the corporate financial reporting of South Asian countries (Ali, Ahmed, \& Henry, 2004). In general, the respective Institutes of Chartered Accountants of the countries of South Asia take the responsibility to adopt IFRS.

Both the Institutes of Chartered Accountants and the Securities and Exchange Commissions of Pakistan and Bangladesh play a vital role in terms of accounting regulation, unlike in other countries in South Asia. In addition, Sri Lanka, Bangladesh, and Maldives adopted both IFRS and IFRS for small and medium-sized enterprises (SMEs). However, Afghanistan, India, Pakistan, and Nepal only adopted IFRS; they have not adopted IFRS for SMEs, and Bhutan has not adopted IFRS or IFRS for SMEs.

\section{Literature Review and Hypotheses Development}

\subsection{Accounting Quality and Conditional Accounting Conservatism}

Accounting quality is defined as the "usefulness of financial reporting to investors" (Hämäläinen \& Martikainen, 2015, p. 297). Accounting quality 
has also been defined as being of "considerable interest to participants in the financial reporting process, including standard setters, preparers, auditors, regulators, analysts, and financial press commentators" (Francis, Olsson, \& Schipper, 2006, p.2). Furthermore, "higher quality earnings more faithfully represent the features of the firm's fundamental earnings process that are relevant to a specific decision made by a specific decision-maker" (Dechow, Ge, \& Schrand, 2010, p.4). In addition, accounting quality has been defined as the "extent to which reported earnings faithfully represent" circumstances (Schipper \& Vincent, 2003, p.2).

In line with previous studies, accounting quality has been measured by a variety of methods, such as discretionary accrual, discretionary revenue, earnings management, earnings smoothing, value relevance, timely loss recognition, and conditional conservatism (Feng, OleKristian, Qingyuan, \& Xin, 2011; Hribar, Kravet, \& Wilson, 2013; Hämäläinen \& Martikainen, 2015; Ding, Jia, \& Wu, 2016). However, revenue models are less biased than accrual models for detecting earnings quality since revenue models detect a combination of revenue and expense manipulation (Stubben, 2010). Therefore, one can argue that conditional accounting conservatism is a less biased method since it is a revenue model. Conservatism has been defined as "capturing accountants' tendency to require a higher degree of verification for recognizing good news than bad news in financial statements" (Basu, 1997, p. 4). In other words, conservatism in earnings is more reflective of "bad" news than "good" news. For example, unrealized losses are generally recognized more quickly than unrealized gains. In addition, accounting conservatism has two dimensions: conditional accounting conservatism and unconditional accounting conservatism.

Conditional accounting conservatism (or ex post or news-dependent) means that the book values of assets and liabilities are written down under adequately adverse circumstances but not the reverse under favourable circumstances (Beaver \& Ryan, 2005). For instance, according to International Accounting Standard (IAS) 2, inventories should be recognized at the lower of cost or net realizable value. Moreover, according to IAS 16 and IAS 36, property, plant, and equipment should be measured with the adjustment of impairment loss. In addition, conditional accounting conservatism can be explained as disclosing highquality accounting information when it is difficult to obtain proper evidence. For instance, firms that employ high-quality accounting are expected to provide high-quality financial information with verifiable evidence, particularly for losses, financial declines, and adverse financial 
transactions (Iatridis, 2011). Thus, firms can disclose high-quality accounting information when it is difficult to obtain verification for the information. This provides conditional conservatism. In addition, asymmetric timelines of gains and losses are also called earnings conservatism or conditional conservatism.

On the other hand, unconditional accounting conservatism (or ex ante or news-independent) means that the characteristics of the accounting process determined at the beginning of the assets and liabilities yield expected unrecorded goodwill (Beaver \& Ryan, 2005). For example, in property, plant, and equipment, depreciation is determined at the beginning based on the expected useful life and the expected scrap value. Furthermore, if a firm provides lower quality disclosure on its financial statements, it encourages unconditional conservatism. Less verifiable information is easier to manipulate. Therefore, it reduces the wealth of both the managers and shareholders of a firm. In addition, managers may act on their own opportunistic agendas if a firm has unconditional conservatism.

Thus, conditional accounting conservatism is a crucial measurement technique in accounting quality (Basu, 1997). It measures timely gain and loss recognition as the tendency for increases and decreases in income to reverse (Basu, 1997). Accounting gains are more permanent than accounting losses since accounting gains are not recognized until realized. Therefore, positive accounting earnings are rarely reversed. On the other hand, negative accounting earnings are reversed more frequently. High-quality accounting information is accompanied by more conditional conservatism and shows less information asymmetry (Ball \& Shivakumar, 2005).

\subsection{FDI and Conditional Accounting Conservatism in the Context of Transitional Economies and Emerging Economies}

Hämäläinen and Martikainen (2015) found that FDI leads the earnings quality measured through conditional conservatism in the transitional economies in Central and Eastern Europe. The transitional economies are changing from a centrally planned economy to a market economy (Feige, 1994). In contrast, emerging economies generally have a less developed industrial base as well as a lower human development index than other economies (Arthur \& Sheffrin, 2003). Therefore, the transitional economies and emerging economies like South Asian countries can be differentiated in terms of three characteristics.

First, is the transparency of policies, meaning that transitional economies have a more market-based approach, and, generally, more 
transparent policies than the emerging economies (Moran, 1998). If a country takes steps to enhance transparency in its policies, FDI can be increased significantly (Drabek \& Payne, 2002).

Second, privatization is also a pertinent factor for differentiating transitional economies and emerging economies. Rolph and György (1997) revealed that privatization influences labour issues in emerging economies and transitional countries. Furthermore, Rolph and György (1997) emphasized that political privatization ${ }^{\dagger}$ still applies in transitional economies. However, it is difficult to see political privatization in developing economies (Rolph \& György, 1997). Uhlenbruck and De Castro (2000) investigated the effect of FDI on privatization in transitional economies. They concluded that foreign acquisitions as a part of FDI present critical managerial issues in transitional economies, such as not fitting with mergers. In contrast, Bahadur (1996) argued that emerging economies have more FDI from privatization.

Moreover, a comparatively large portion of FDI from privatization can be seen in emerging economies (Bahadur, 1996). In particular, Bahadur (1996) highlighted that South Asian countries show 4.03 per cent of FDI from privatization as a percentage of total FDI whereas Central and Eastern Europe show 1.27 per cent. Third, IFRS adoption can also be taken into consideration to differentiate transitional economies and emerging economies. According to the IFRS Foundation (2016), many European countries, as transitional economies, adopted IFRS under the EU agreement in 2002. However, particularly, South Asian countries, as emerging economies, adopted IFRS after 2002 (IFRS Foundation, 2016).

As differences exist between transitional economies and emerging economies, conditional accounting conservatism affects FDI differently. For instance, Ball and Shivakumar (2005) argued that conditional accounting conservatism reduces the managerial incentive to accept investments that have a negative net present value, particularly in transitional economies. This means that if the net present value of an investment is negative, the entire investment should be rejected. However, managers would accept the investment based on the incentives to be received. However, Ball and Shivakumar (2005) reported that with high conditional accounting conservatism at the same time, incentives for unacceptable investments would be reduced.

$\dagger$ Political privatization means that all citizens are provided shares of public enterprises regardless of their economic capability. 
Therefore, the expected return on investment could be achieved through the proper selection of investment. Even so, Kravet (2014) revealed that managers make less risky investments under higher accounting conservatism in transitional economies. Managers in highly conservative firms would not accept a risky investment even though the particular investment is profitable. As a result, the return on investment will decrease since managers accept the less risky investment. A wellknown theory in finance suggests that if the risk of an investment is high, the return is also high. Thus, the overall return on investment would drop in high conditional accounting conservatism. However, few prior studies have investigated how conditional accounting conservatism influences FDI in emerging economies. In light of the arguments regarding FDI and conditional accounting conservatism, as well as the differences between transitional economies and emerging economies, the following hypotheses are proposed:

H1: FDI positively affects conditional accounting conservatism in South Asia.

H2: $\quad$ FDI positively affects conditional accounting conservatism in India.

H3: $\quad$ FDI positively affects conditional accounting conservatism in Pakistan.

H4: FDI positively affects conditional accounting conservatism in Bangladesh.

H5: FDI positively affects conditional accounting conservatism in Sri Lanka.

\section{Data and Methods}

\subsection{Sample Selection and Research Model}

Accounting data for public listed companies in emerging countries in South Asia are derived from Oriana - a company information Asia Pacific database - while information for the FDI of South Asian countries is derived from the World Bank database. The sample consists of listed non-financial companies in India (3,531 companies), Pakistan (403 companies), Bangladesh (86 companies), and Sri Lanka (203 companies). The final sample consists of 42,228 firm-year observations for the years 2006-2015. To measure conditional conservatism, this study used the model originally developed by Basu (1997). The model was modified by Ball and Shivakumar (2005) to measure conditional conservatism based on changes in company net income. In addition, Hämäläinen and Martikainen (2015) later modified the model to include the effect of 
country-level FDI. The following regression model is used to test the hypotheses of this study.

$$
\begin{aligned}
\Delta N I_{t}= & a_{0}+a_{1} D+a_{2} \Delta N I_{t-1}+a_{3} D^{*} \Delta N I_{t-1}+a_{4} L F D I+a_{5} D^{*} L F D I+ \\
& a_{6} \Delta N I_{t-1}^{*} L F D I+a_{7} D^{*} \Delta N I_{t-1}^{*} L F D I+\varepsilon
\end{aligned}
$$

where

$\Delta N I_{t}$ represents the change in net company income from fiscal year to previous fiscal year $\left(N I_{t}-N I_{t-1}\right)$ scaled by total assets at the beginning of the period.

$D$ represents the dummy variable taking the value of 1 if the prioryear change income is negative and 0 otherwise.

LFDI represents the foreign direct investment in log.

\subsection{Measures of Conditional Accounting Conservatism}

The dependent variable is the company income change $\left(\Delta N I_{t}\right)$. Conditional accounting conservatism is measured by a firm's reversal of income. Since accounting profits are not anticipated in a firm, conditional accounting conservatism is seen as a good measure of accounting quality. In formula form, this change in earnings can be written as follows.

$$
\text { Income change }\left(\Delta N I_{t}\right)=\frac{N I_{t}}{\text { Total }} \frac{-N I_{t-1}}{\text { Assets }}
$$

where

$\Delta N I_{t}$ represents the change in net company income from fiscal year

to previous fiscal year $\left(N I_{t}-N I_{t-1}\right)$ scaled by total assets at the beginning of the period.

$N I_{t}$ represents the net company income in the fiscal year.

$N I_{t-1}$ represents the net company income in the previous fiscal year.

\subsection{Measures of FDI and Other Variables}

LFDI represents the logarithms of foreign direct investments, nondichotomous in nature. In this study, a non-dichotomous variable of LFDI has been taken into consideration, unlike in the study by Hämäläinen and Martikainen (2015), which took a dichotomous variable for FDI. The model used in this study can be differentiated from the model used by Hämäläinen and Martikainen (2015), which is seen from the result of the predictor variable of both models. This study conducted sensitivity testing for the FDI variable, which was considered a dummy variable with the value of 1 if the country-level FDI was greater than the median country-level FDI. Lower coefficient values for the predictor 
variable were shown in the sensitivity test, in contrast to the result of the main regression of the study. The main regression showed a higher coefficient value for the predictor variable.

Furthermore, Alunan and Royston (2006) argued that dichotomizing creates several problems in a regression. First, information loss can occur because the accuracy of the statistical outcome is reduced. Second, dichotomizing hides any non-linearity in the relation between the variable and the outcome. Third, a reader might underestimate the variation in outcome. Moreover, dichotomization creates problems rather than avoiding them since massive amounts of information could be lost (Royston, Altman, \& Sauerbrei, 2006). Furthermore, converting continuous data into dummy/dichotomous variables might be unnecessary for the statistical analysis (Royston et al., 2006). However, real data exhibit more characteristics and have considerable simulation and feasibility in distribution (Stigler, 1977).

The next variable, $\mathrm{D}$, has a value of 1 if the previous year's income change is negative and 0 otherwise. Moreover, $\Delta \mathrm{NIt}-1$ is the income change in the previous year. This study predicts that the coefficient of $\alpha 7$ $<0$, which is represented as $\mathrm{D}^{*} \Delta \mathrm{NIt}-1^{*} \mathrm{LFDI}$, is the result of the multiplication of the dummy, income change in previous year, and the logarithm of foreign direct investments. $\mathrm{D}^{*} \Delta \mathrm{NIt}-\mathrm{1}^{*} \mathrm{LFDI}$ measures the incremental conditional conservatism. Moreover, it predicts that for countries that show high FDI, incremental conditional conservatism (timely loss recognition) is high. This study offers no prediction for the intercept and incremental intercept of the coefficients of a1, a2, a3, a4, a5, and a6.

\section{Empirical Results}

\subsection{Descriptive Statistics and Correlation}

Table 1. Descriptive statistics of the dependent variable

\begin{tabular}{lrrrrrrr}
\hline Country & $\mathrm{N}$ & Mean & Median & Min & Max & Std. D. & $\Delta N I_{t}<0$ \\
\hline All & 42,228 & 15.184 & 0.026 & $-50,778$ & 138,778 & 1,132 & $41.02 \%$ \\
India & 35,308 & 17.193 & 0.024 & $-50,732$ & 138,778 & 1,207 & $41.49 \%$ \\
Pakistan & 4,030 & 0.615 & 0.027 & $-2,109$ & 399 & 38.75 & $42.28 \%$ \\
Bangladesh & 860 & 0.991 & 0.067 & -91.324 & 125 & 10.17 & $30.00 \%$ \\
Sri Lanka & 2030 & 3.006 & 0.034 & -8.895 & 4625.23 & 102.954 & $34.82 \%$ \\
\hline
\end{tabular}

Table 1 provides a summary of the statistics of the mean, median, minimum, maximum, and standard deviations of the sample of 42,228 firm-year observations from 2006 through 2015. Descriptive statistics for 
$\Delta N I \mathrm{t}$ for the whole sample and the individual countries of India, Pakistan, Bangladesh, and Sri Lanka are presented.

The mean value of the dependent variable of income change ranges from a high of 17.193 (India) to a low of 0.615 (Pakistan). The highest median value is 0.067 in Bangladesh while the lowest is 0.024 in India. The percentage of negative changes of income scaled by total assets at the beginning of the year fluctuates in the range of 30 per cent to 42.28 per cent, with the lowest in Bangladesh and the highest in Pakistan.

Table 2. Correlation matrices for the whole sample, India, Pakistan, Bangladesh, and Sri Lanka

\begin{tabular}{|c|c|c|c|c|c|}
\hline Country & & $\Delta N I_{t}$ & $D$ & $\Delta N I_{t-1}$ & $\overline{L F D I}$ \\
\hline \multirow{4}{*}{$\begin{array}{l}\text { Whole } \\
\text { sample }\end{array}$} & $\Delta N I_{t}$ & 1.000 & & & \\
\hline & $D$ & 0.002 & 1.000 & & \\
\hline & $\Delta N I_{t-1}$ & -0.009 & -0.021 & 1.000 & \\
\hline & LFDI & 0.007 & 0.032 & 0.003 & 1.000 \\
\hline \multirow{4}{*}{ India } & $\Delta N I t$ & 1.000 & & & \\
\hline & $D$ & 0.001 & 1.000 & & \\
\hline & $\Delta$ NIt-1 & -0.009 & -0.023 & 1.000 & \\
\hline & LFDI & 0.015 & 0.019 & 0.006 & 1.000 \\
\hline \multirow{4}{*}{ Pakistan } & $\Delta N I t$ & 1.000 & & & \\
\hline & $D$ & 0.035 & 1.000 & & \\
\hline & $\Delta$ NIt-1 & -0.219 & -0.108 & 1.000 & \\
\hline & LFDI & 0.016 & -0.108 & -0.028 & 1.000 \\
\hline \multirow{4}{*}{ Bangladesh } & $\Delta$ NIt & 1.000 & & & \\
\hline & $D$ & -0.020 & 1.000 & & \\
\hline & $\Delta N I t-1$ & -0.173 & -0.140 & 1.000 & \\
\hline & LFDI & 0.091 & 0.102 & 0.028 & 1.000 \\
\hline \multirow{4}{*}{ Sri Lanka } & $\Delta N I t$ & 1.000 & & & \\
\hline & $D$ & 0.033 & 1.000 & & \\
\hline & $\Delta$ NIt-1 & -0.004 & -0.073 & 1.000 & \\
\hline & LFDI & -0.032 & 0.054 & -0.020 & 1.000 \\
\hline
\end{tabular}

Notes: $\Delta N I_{t}$ represents the change in income from fiscal year $t-1$ to $t$ (defined $I N_{t}-I N_{t-1}$ ) scaled by total assets at the beginning of the period. $D$ represents the Dummy variable taking the value of 1 if the prior-year change $\Delta N I_{t-1}$ is negative and 0 otherwise. LFDI represents the Logarithm value of real foreign direct investment.

Table 2 presents the correlation metrics for the variables of this empirical study for the whole sample, India, Pakistan, Bangladesh, and Sri Lanka. $\Delta N I \mathrm{t}$ is the change in income from fiscal year ${ }_{t}$ to $t-1$ scaled by total assets at the beginning of the year. $\mathrm{D}$ is a dummy variable, with a value of ${ }_{1}$ if the previous year income change is negative and 0 otherwise. $\Delta N I_{t-1}$ is the firm's change in income in a previous year and LFDI stands for the logarithm of foreign direct investment. Overall, correlation of the 
variables varies in the range of -0.219 to 0.102 , with the lowest correlation in $\Delta N I_{t}$ to $\Delta N I_{t-1}$ and the highest in the dummy to LFDI.

In the whole sample, the correlation fluctuated in the range of -0.021 to 0.032. However, in India, the correlation ranged from -0.023 to 0.019 . Pakistan shows the highest positive correlation of 0.035 between the variables $\Delta N I_{t}$ and the dummy, while the highest negative correlation is -0.219 between the variables $\Delta N I_{t}$ and $\Delta N I_{t-1}$. In Bangladesh, the highest and lowest correlation of variables is -0.173 and 0.102 , respectively. In addition, Sri Lanka showed -0.073 and 0.054 correlation values as the lowest and highest.

\subsection{Regression Model}

Table 5 presents the results of the effect of FDI on conditional accounting conservatism in the whole sample - India, Pakistan, Bangladesh, and Sri Lanka. The results indicate incremental conditional accounting conservatism in all regressions of the whole sample - India, Pakistan, and Bangladesh. However, in Sri Lanka, a positive sign is seen for the predictor variable even though it is statistically significant. The positive coefficient indicates that there is no incremental conditional accounting conservatism. For the whole sample, a negative coefficient of -2.08 is displayed, which is statistically significant. Therefore, the first hypothesis, "FDI positively affects conditional accounting conservatism in South Asia," can be accepted for the whole sample. This finding is consistent with that of Hämäläinen and Martikainen (2015) in that FDI affects the accounting quality in the transitional economies of Europe. In addition, this regression shows 11.61 per cent and 2.31 per cent for the $\mathrm{R}^{2}$ value and adjusted $\mathrm{R}^{2}$ value, respectively. Generally, low $\mathrm{R}^{2}$ values are seen in the studies conducted by Ball and Shivakumar (2005), and Hämäläinen and Martikainen (2015). Furthermore, the F-statistic value of this regression is 1.18, with a significant P-value. In addition, the Hannan-Quinn criterion is 726,455 , while the Durbin-Watson statistic is recorded as 1.53 .

Furthermore, the analysis is extended to measure the relationship between FDI and conditional accounting conservatism in the individual countries of India, Pakistan, Bangladesh, and Sri Lanka. In India, the coefficient of $\alpha 7$ is -2.07 , which is statistically significant. The $R^{2}$ value of the regression is 11.64 per cent and the adjusted $\mathrm{R}^{2}$ value is 2.34 per cent. The F-statistic value is 1.18, with a significant P-value. Also, the HannanQuinn criterion is 613,583 while the Durbin-Watson statistic is recorded as 1.53. The coefficient of $a 7$ in India increased by $0.01(2.08-2.07)$ when 
compared with the whole sample. Thus, H2 hypothesis, FDI positively affects conditional accounting conservatism in India, can be accepted.

Table 5 also illustrates the results of the regression for Pakistan. The coefficient of the predictor variable is -1.76 , which is statistically significant. The $\mathrm{R}^{2}$ value of the regression is 17.18 per cent, which is a higher value when compared with the regressions of the whole sample and India. The adjusted $R^{2}$ is 10.87 per cent, which is also a higher value when compared with the regressions of the whole sample and India. The Hannan-Quinn criterion is 41,889 , while the Durbin-Watson statistic is 1.41. The F-statistic value is 1.84 , with a significant P-value. When the coefficient of the predictor variable in Pakistan is compared with that of India, the negative coefficient has decreased from -2.07 to -1.76 , which reflects 15 per cent lower incremental conditional accounting conservatism than in India. However, H3 hypothesis, FDI positively affects conditional accounting conservatism in Pakistan, can be accepted since it has a significant $\mathrm{P}$-value for the predictor variable.

Moreover, Bangladesh shows -1.37 for the coefficient of $a 7$, which is also statistically significant. The $\mathrm{R}^{2}$ value of the regression is 17.51 per cent and the adjusted $\mathrm{R}^{2}$ value is 12.51 per cent. The Hannan-Quinn criterion is 6,619 while the Durbin-Watson statistic is 1.71 . The F-statistic value is 1.77 , with a significant $\mathrm{P}$-value. Thus, incremental conditional accounting conservatism is reduced further from the result of this regression. Even though incremental conditional conservatism is reduced in this regression, the $\mathrm{H} 4$ research hypothesis of this study, FDI positively affects conditional accounting conservatism in Bangladesh, can be accepted.

With respect to Sri Lanka, a considerably higher coefficient for the predictor variable can be seen, unlike other regressions of the study. However, the predictor variable is statistically significant. The coefficient of $\alpha 7$ is 374.40 . The $R^{2}$ value and the adjusted $R^{2}$ value are 11.13 per cent and 1.34 per cent, respectively. The Hannan-Quinn criterion is 25,188 while the Durbin-Watson statistic is 1.12. The F-statistic value is 1.09, with an insignificant P-value. Therefore, there is no incremental conditional accounting conservatism in Sri Lanka. Sri Lanka recorded less FDI than other countries in the sample. This may have resulted in the positive sign in the predictor coefficient. Therefore, Sri Lanka does not show conditional accounting conservatism to meet the information needs of foreign investors. Thus, H5, FDI positively affects conditional accounting conservatism in Sri Lanka, can be rejected. 


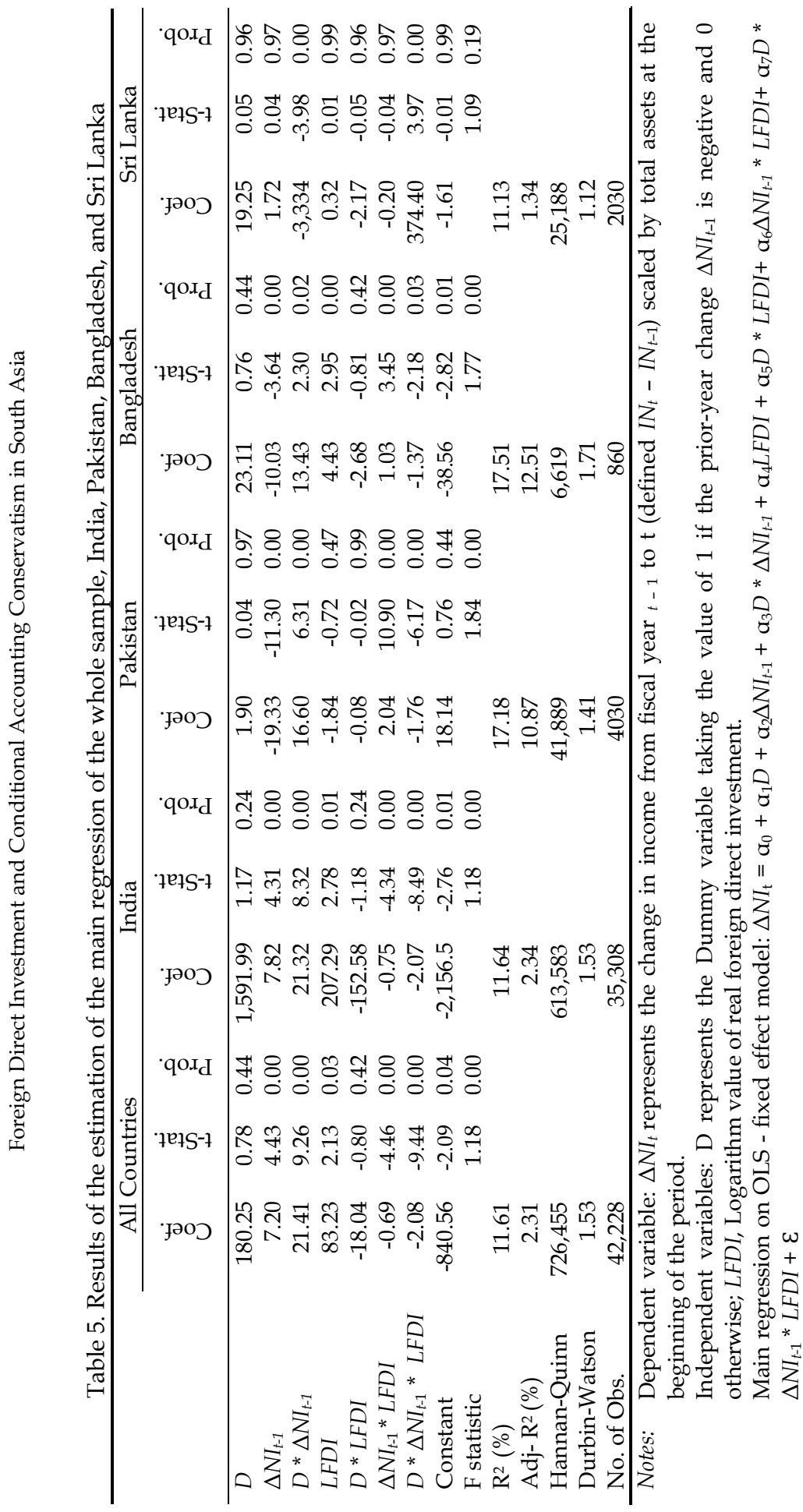


In the panel OLS, two alternative methods are available to analyse the data. They are the fixed effect model and random effect model. The most appropriate methods could be selected based on the results of the Hausman test. In the Hausman test, a null hypothesis shows that the random effect model is more appropriate. While the alternative hypothesis suggests that the fixed effect model is appropriate.

The result of the Hausman test is a negligible P-value. Thus, the null hypothesis was rejected, and, as a result, the fixed effect model is more appropriate for this study. Therefore, the results of the main regression and regression of the sensitivity test were obtained from the panel OLS fixed effect model.

\subsection{Sensitivity Testing}

Since a degree of arbitrariness exists in choosing the proxies for the independent variables of the regression, a sensitivity test was run by changing the mode of an independent variable to ensure the robustness of the result. In the main regression, LFDI was used as an independent variable. However, in the sensitivity testing, the LFDI variable was changed to a dummy variable with a value of 1 if the country-level FDI is higher than the country-level median FDI value and 0 otherwise.

Table 6 illustrates the results of the sensitivity testing for the whole sample, India, Pakistan, Bangladesh, and Sri Lanka. Overall, the coefficient of the predictor variable of the study was drastically reduced. The $R^{2}$ values and adjusted $R^{2}$ values of the sensitivity regressions changed more than in the main regressions of the study. A detailed description of how the result of sensitivity testing changed from the main regression on the whole sample - India, Pakistan, Bangladesh, and Sri Lanka - is given below.

In the whole sample, the coefficient of the predictor variable dropped from -2.08 (main regression) to -0.86 (sensitivity test). In addition, the $R^{2}$ value and adjusted $R^{2}$ value of the regression of sensitivity test are 11.91 per cent and 2.63 per cent, respectively. The $\mathrm{R}^{2}$ value and adjusted $\mathrm{R}^{2}$ value of the regression of sensitivity testing are slightly higher than in the main regression. Moreover, in India, the coefficient of the predictor variable is -0.86 . However, the coefficient of the main regression is -2.07 . In terms of the $R^{2}$ value and adjusted $R^{2}$ value of the sensitivity regression of India, similar changes can be seen, which are described in the whole sample. 


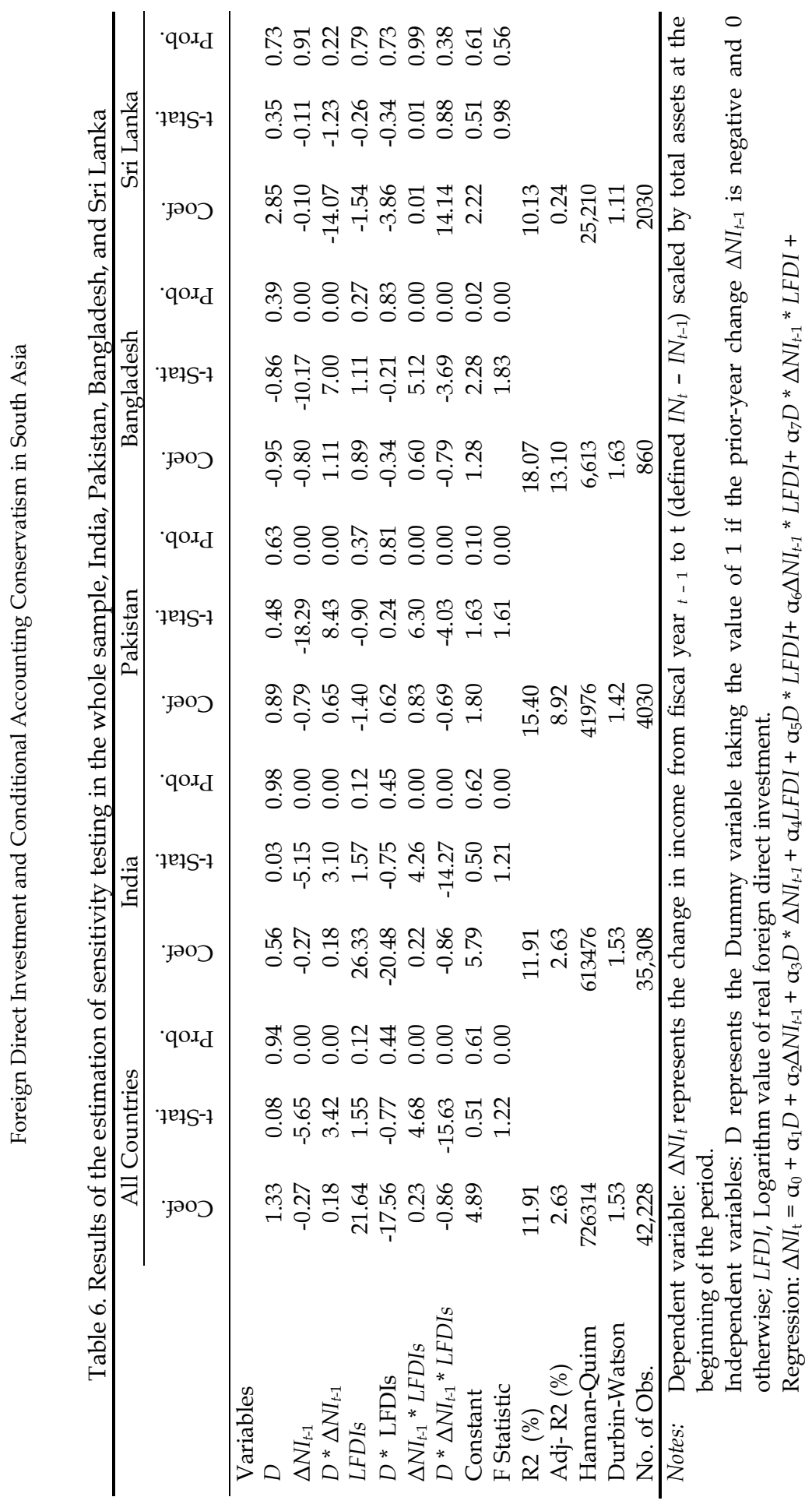

พ 
However, a slight drop is seen in the $\mathrm{R}^{2}$ value and adjusted $\mathrm{R}^{2}$ value in the sensitivity regression of Pakistan. A 1.78 per cent (17.18 per cent 15.40 per cent) drop is seen in the $\mathrm{R}^{2}$ value, while a 1.95 per cent (10.878.92) drop is seen in the adjusted $R^{2}$ value in the regression of sensitivity testing compared to the main regression of Pakistan. In addition, the coefficient of the predictor variable is -0.69 , which declined by 60.79 per cent (1.76-0.69/1.76) when compared with the main regression. On the other hand, the $\mathrm{R}^{2}$ value and adjusted $\mathrm{R}^{2}$ value in the sensitivity testing regression in Bangladesh rise slightly compared to the main regression.

Furthermore, the coefficient of the predictor variable of Bangladesh is -0.79 . In the sensitivity testing regression for Sri Lanka, the coefficient of the predictor variable dropped from 374.40 (main regression) to 14.14 (sensitivity test). On the other hand, a slightly higher $\mathrm{R}^{2}$ value can be seen in the sensitivity testing regression compared with the main regression in Sri Lanka.

However, the adjusted R2 value has dropped from 1.34 per cent to 0.24 per cent. In addition, the significant predictor variable in the main regression is insignificant in the sensitivity testing regression of Sri Lanka. Therefore, in light of the result of sensitivity testing, one can argue that the FDI variable is a sensitive variable for the regression. In terms of the coefficient of the predictor variable, there is a massive decline when the LFDI variable changes to DFDI. Therefore, the main model used in this study makes a contribution to the literature.

\section{Conclusion}

In this study, the relationship between FDI and conditional accounting conservatism in South Asia is examined by using the model developed by Basu (1997), and modified by Ball and Shivakumar (2005), and Hämäläinen and Martikainen (2015). The results indicate that FDI and conditional accounting conservatism have a significant positive relationship in South Asia as a whole, as well as in the individual countries of India, Pakistan, and Bangladesh. This means that India, Pakistan, and Bangladesh show more conditional accounting conservatism and one can conclude that these three countries provide high-quality accounting information to foreign investors to meet their information needs. However, Sri Lanka does not show incremental conditional accounting conservatism; indeed, Sri Lanka shows less conditional accounting conservatism and thus information asymmetry, particularly for foreign investors. The level of FDI in Sri Lanka is lower than in the other three countries of India, Pakistan, and Bangladesh. In addition, the results show that the level of incremental conditional 
conservatism positively relates to the level of FDI in the sample countries of India, Pakistan, and Bangladesh.

Based on the results, this study presents evidence of higher incremental conditional accounting conservatism for FDI in emerging economies than in transitional economies. This may occur due to the differences highlighted in this study, such as socialist ownership, transparent policies, and IFRS adoption. For instance, Hämäläinen and Martikainen (2015) reported a significantly negative coefficient of -0.500 for the predictor variable, which reflects incremental conditional accounting conservatism, while the present study shows a -0.860 coefficient for the predictor variable. This means that foreign direct investors in emerging economies expect highly conservative financial statements compared to foreign direct investors in transitional economies.

In addition, this study found that a dummy variable for FDI and real data for FDI have a significantly different impact on incremental conditional accounting conservatism. Therefore, this is evidence that the FDI variable is a sensitive variable for the result. For example, when LFDI changes to DFDI, the coefficient of the predictor variable drastically drops. Even though this decreased dramatically in the sensitivity testing regression, it is higher than the coefficient value for the predictor variable found by Hämäläinen and Martikainen (2015) for transitional economies.

This study has two implications. First is the theory implication; this study shows new evidence that emerging economies show higher incremental conditional accounting conservatism for FDI than transitional economies. In addition, the study contributes to the literature in terms of the model; the findings contribute by providing new evidence that a dummy variable for FDI shows lower incremental conditional accounting conservatism, while the real data for FDI show higher incremental conditional accounting conservatism. Second is the policy implication; the results of this study will be useful to policymakers and authoritative accounting bodies in emerging economies because the study demonstrates that more highly conservative financial reporting is needed to attract FDI in emerging economies than in transitional economies. Therefore, policymakers can benefit from the study by understanding why highly conservative financial statements are needed to attract high FDI. 


\section{References}

Ali, M. J., Ahmed, K., \& Henry, D. (2004). Disclosure compliance with national accounting standards by listed companies in South Asia. Accounting and Business Research, 34(3), 183-199.

Altman, D. G., \& Royston, P. (2006). The cost of dichotomising continuous variables. British Medical Journal, 322, 1080.

Arthur, S., \& Sheffrin, S. (2003). Economics: Principles in action: Pearson Prentice Hall.

Bahadur, F. (1996). Foreign direct investment through privatization in development countries. Tribhuvan University Journal, 19(2), 105-110.

Ball, R., \& Shivakumar, L. (2005). Earnings quality in UK private firms: comparative loss recognition timeliness. Journal of Accounting and Economics, 39(1), 83-128.

Basu, S. (1997). The conservatism principle and the asymmetric timeliness of earnings Journal of Accounting and Economics, 24(1), 3-37.

Beaver, W. H., \& Ryan, S. G. (2005). Conditional and unconditional conservatism: Concepts and modeling. Review of Accounting Studies, 10(2-3), 269-309.

Daniel, C., \& Andres, L. (1999). Globalization and developing countries: Foreign direct investment and growth and sustainable human development. Geneva: United Nations.

Dechow, P. M., Ge, W., \& Schrand, C. M. (2010). Understanding earnings quality: A review of the proxies, their determinants and their consequences. Journal of Accounting and Economics, 50(2,3), 344-401.

Ding, S. J., Liu, M. Z., \& Wu, Z. Y. (2016). Financial reporting quality and external debt financing constraints: The case of privately held firms. Journal of Accounting Finance and Business Studies, 52(3), 351-373.

Drabek, Z., \& Payne, W. (2002). The impact of transparency on foreign direct investment. Journal of Economic Integration, 777-810.

Emeni, F. (2014). Foreign direct investments and international financial reporting standards adoption in Africa. Ushus Journal Business Management, 13(3), 27-44.

Feige, E. L. (1994). The transition to a market economy in Russia: property rights, mass privatization and stabilization. A fourth way, 57-78.

Feng, C., Ole-Kristian, H., Qingyuan, L., \& Xin, W. (2011). Financial reporting quality and investment efficiency of private firms in emerging markets. The Accounting Review, 86(4), 1255-1288.

Fortin, H., Barros, A. C., \& Cutler, K. (2010). Accounting for growth in Latin America and the Caribbean: improving corporate financial reporting to support regional economic development: World Bank Publications. 
Francis, J., Olsson, P., \& Schipper, K. (2006). Earnings quality. Foundations and Trends in Accounting and Finance, 1(4), 259-340.

Hämäläinen, S., \& Martikainen, M. (2015). Foreign direct investments affecting accounting quality in transitional economies of Europe International Journal of Business Innovation and Research, 9(3), 295-310.

Hribar, P., Kravet, T., \& Wilson, R. (2013). A new measure of accounting quality. Review of Accounting Studies, 19(1), 506-538.

Iatridis, G. E. (2011). Accounting disclosures, accounting quality and conditional and unconditional conservatism. International Review of Financial Analysis, 20(2), 88-102.

IFRS Foundation. (2016). IFRS use around the world - Jurisdiction profiles. Retrieved from http://www.ifrs.org/

Kravet, T. D. (2014). Accounting conservatism and managerial risktaking: Corporate acquisitions. Journal of Accounting $\mathcal{E}$ Economics, 57(2-3), 218-240.

Laura, A., Areendam, C., Sebnem, K.-O., \& Selin, S. (2004). FDI and economic growth: The role of local financial markets. Journal of International Economics, 64(1), 89-112.

Luo, Y., \& Peng, M. (1998). First mover advantages in investing transitional in economies. Thunderbird International Business Review, 40(2), 141-163.

Moran, T. H. (1998). Foreign direct investment and development: The new policy agenda for developing countries and economies in transition: Peterson Institute.

Rolph, V. d. H., \& György, S. (1997). Lessons from privatization: Labour issues in developing and transitional countries: International Labour Organization.

Royston, P., Altman, D. G., \& Sauerbrei, W. (2006). Dichotomizing continuous predictors in multiple regression: A bad idea. Journal of Stantistics in Medicine, 25(1), 127-141.

Sahoo, P., Nataraj, G., \& Dash, R. K. (2014). Foreign direct investment in South Asia: Policy, impact, determinants and challenges: Springer India.

Schipper, K., \& Vincent, L. (2003). Earnings quality. Journal of Accounting Horizons, 17, 97-110.

Stigler, S. M. (1977). Do robust estimators work with real data? The Annals of Statistics, 5(6), 1055-2098.

Stubben, S. R. (2010). Discretionary revenues as a measure of earnings management. The Accounting Review, 85(2), 695-717.

Uhlenbruck, K., \& De Castro, J. O. (2000). Foreign acquisitions in Central and Eastern Europe: Outcomes of privatization in transitional economies. Academy of Management Journal, 43(3), 381-402. 
Foreign Direct Investment and Conditional Accounting Conservatism in South Asia

World Bank. (2016). South Asia Countries World Bank. Retrieved from http://web.worldbank.org/ 